\title{
Market Risk Hedging Strategy and Financial Performance at Nigeria Stock Exchange Listed Banks
}

\author{
Temitope Adesina ${ }^{1, *} \quad$ Tabitha Nasieku, $\mathrm{PhD}^{1} \quad$ Oluoch Oluoch, $\mathrm{PhD}^{2}$ \\ 1.Department of Economics, Accounting and Finance (DEAF), \\ 2.Department of Business Administration (DBA) Jomo Kenyatta University of Agriculture and Technology, \\ Kenya
}

\begin{abstract}
:
The main objective of the study was to determine the Market Risk Hedging strategy and financial performance of listed banks at Nigeria Stock Exchange (NSE). Contingency theory and Agency theory were used to expound on the effect of market risk hedging strategy and financial performance. Longitudinal cross sectional survey research design was adopted. The study's target population includes all the 28 listed banks at Nigeria stock exchange. Data was collected from 2009 to 2018 for 20 listed banks in Nigeria. The secondary data sources for the period of between 2009 and 2018 were collected from Nigeria Stock Exchange and annual reports and accounts of the listed banks. The data was collected from audited financial statements of listed banks and other relevant internal report. Data collected was subjected to diagnosis tests of normality, autocorrelation, multicollinearity, linearity, homoscedasticity, stationarity, fixed and random effects. Correlation analysis was carried out to establish the relationship between the dependent and independent variables. Generalized Least Squares (GLS) regression analysis model was used to establish the relationship and significance between the study variables. The formulated hypotheses were tested. STATA statistical software version 10 was used for data analyses. The study found out that there are positive relationship between market risk hedging strategy and price earnings ratio which is the measure of financial performance of the listed banks at NSE. Based on the findings, the study concluded that Market Risk Hedging Strategies have a significant effect on financial performance of listed banks at NSE. The study recommends that there is need for the listed banks to effectively manage their risk as it was found that risk management positively influence financial performance of listed banks. The study further recommends that there is need for the management of listed banks to constantly check their banks' exposure to credit risk, insolvency risk, and interest rate sensitivity.
\end{abstract}

Keywords: Market Risk Hedging, Financial Performance.

DOI: $10.7176 / \mathrm{EJBM} / 12-15-11$

Publication date:May $31^{\text {st }} 2020$

\section{Introduction}

Market Risk Hedging Strategy is geared to address risks that can occur to a business organization such as financial risks, strategic risks and operation risks (Tazhir \& Razali, 2012). Weak risk management system was a major contributing factor to the financial crisis in United States of America (USA) in 2008. The crisis affected the economy and financial markets in the USA leading to collapse of the mortgage industry (Soludo, 2004). All financial institutions aim to perform effectively, manage the business risks, comply with laws and regulations, and prepare reliable financial statements. However, during the operations, they expose to the potential risk of not achieving these objectives due to weaknesses of managers, staff or a third person that cause risks and reduce their performance. Building Market Risk Hedging strategy is one of the solutions to evaluate and manage risks, improve performance effectiveness and achieve business objectives. In recent years, the commercial bank system in Vietnam has considerably developed in term of asset size, branch-office system, products and services, and the information technology system. However, besides growth in size and profit, the bank system is facing many limits, weaknesses and has potential risks.

Market Risk Hedging (MRH) has been widely discussed by both researchers and the practitioners as a holistic and effective approach to managing the wider range of risks faced by business MRH. It is expected that effective risk management practices enable business managers creating and protecting long term MRH value and assuring the long term stability and growth. Especially, in the context of global financial crisis (2008) and corporate scandals and high profile corporate failures (Eikenhout, (2015) the concept of MRH gained an increased attention among corporate managers. Prior to the emergence of the concept of MRH as a holistic approach to manage the risk, market risk hedging used to manage their risk factors on "case by case" basis which said to be a traditional and less effective approach. While the banking system tends to expand in size, its performance is unstable, and lots of risks arise and need to be resolved like bad debt, potential bankruptcy of banks. One of the urging strategic solutions is to establish and upgrade risk monitoring of commercial banks (Salehi, 2008). Market Risk Hedging becomes an important self-defense system against risks, which enhances effectiveness of banks' performance. 


\section{Market Risk Hedging Strategy in Nigeria Banking System.}

Business MRH in the modern pristine capitalistic economy mainly focus on adding value to the shareholders. Adoption of any new technology, methodology or management approach is expected to be adding value to the $\mathrm{MRH}$, for it to be accepted by the industry. The concept of Market Risk Hedging (MRH) as a financial and strategic approach to manage the risk facing by a business, is expected to enhance MRH' performance. The proposition, as to whether the adoption of Market Risk Hedging strategy (MRH) has an impact on the financial performance of banks has long been discussed by both practitioners and academia. A considerable number of researchers have significantly contributed to the body of knowledge of the MRH's impact on financial performance through their empirical studies.

Adebiyi (2016) advocate that lack of appropriate risk management implementation in the Nigerian banks is vulnerable to risk management failure and tantamount to fraud. Likewise, Owojor et al. (2011) advanced support in this way. The $\mathrm{CBN}$ also highlights many deficiencies in the information disclosed especially in the field of risk management strategies, performance criteria, and risk concentration. The CBN further indicate that such defects will need to be a holistic and integrated plan of action. Other challenges in the Nigerian banking sector include; inadequate management capacity, ineffective board/statutory audit committee and continued concealment. Furthermore, others include inadequate operational and financial controls as a result of weak internal control, insider-related lending and rendition of false returns. Other problems highlighted are; lack of transparency and adequate disclosure of information, and technical incompetence of board and top management to play a strategic role and improve performance due to complexity and diversification.

Amidst the global economic crisis in 1998 and 2008, high profile corporate scandals and business failures such as Barings Bank (1995), Enron (2001), WorldCom (2002), the emerging concept of Risk management (RM) has been widely discussed by the academia and the practitioners in the recent past. Risk management has been highly considered by today's corporate managers as a strategic approach to managing risk face by business market risk hedging in an integrated way as oppose to traditional silo-based risk management. Despite there is a growing concern on the adoption of RM practices with the key objective of enhancing MRH value, there is little empirical evidence supporting the value relevance of the RM implementation. Prior researchers have made some attempts to empirically verify the relationship between RM and MRH performance and find mixed results about the value relevance of the RM implementation.

\section{Financial Performance of Commercial Banks in Nigeria.}

Financial Performance in broader sense refers to the degree to which financial objectives has been accomplished and is an important aspect of risk management. It is the process of measuring the results of a MRH's policies and operations in monetary terms (Damondaran 2013). The significant changes that have occurred in the financial sector of developing economy like Nigeria have increased the importance of performance analysis of modern banks. Casu et al (2006) observed that performance analysis is an important tool used by various agents operating either internally to the bank or who form part of the bank's external operating environment. Among the large set of performance measures for banks used by academics and practitioners alike, a distinction can be made between traditional, economic and market-based measures of performance. Traditional measures of performance are similar to those applied in other industries, with return on assets (ROA), return on equity (ROE) or price earning $(\mathrm{P} / \mathrm{E})$ ratio being the most widely used as external measure of performance. In addition, given the importance of the intermediation function for banks, net interest margin is typically monitored. The return on assets (ROA) is the net income for the year divided by total assets, usually the average value over the year. Return on assets equals net income / average total assets.

Another major yardstick for measuring performance in the banking industry is the CAMEL approach. This approach is equally used by the monitoring authority to assess the level of performance of banks, before making any pronouncement on their soundness, solvency and liquidity position. The acronym CAMEL means: $\mathrm{C}=\mathrm{Capital}$ Adequacy $\mathrm{A}=$ Assets $\mathrm{M}=$ Management $\mathrm{E}=$ Earning $\mathrm{L}=$ Liquidity. This serves as a major tool for assessing solvency level of banks by the monitoring authority.

\section{Research problem}

Despite the rising importance of Market Risk Hedging strategy (MRH), there is a deficiency of empirical evidence to evaluate the current state of Market Risk Hedging practices in the Nigerian banking industry. Very few MRH have implemented MRH. Furthermore, the subject area of risk management is scarce as there are only a few studies on risk management in Nigeria. Paradoxically, all the studies empirically failed to assess the current state of MRH practices in the Nigerian banking industry. Some of the studies that examine risk management include; (Ajibo, 2015; Fadun, 2013; Doaei et al., 2014; Santarelli \& Tran, 2013; Anastasiadou, 2011); Njogo, 2012; Owojori, Akintoye \& Adidu, 2011). The Central Bank of Nigeria (CBN, 2012) maintains that risk management is still at its rudimentary stage and is bedevilled by some challenges. These challenges include inadequate knowledge of risk management by members of the board of many banks and lack of professionals. Others are a lack of risk training 
and education and lack of a framework that defends the growth of skilled and capable workers in the industry (CBN, 2011 \& 2012). Thus, the primary aim of this research is to analyze the Market Risk Hedging strategy and financial performance of listed banks at Nigeria Stock Exchange.

\section{Objectives}

To establish the effect of market risk hedging strategy on financial performance of listed banks at Nigeria Stock Exchange.

\section{Research Hypotheses}

Ho1 Market risk hedging strategy has no significant effect on financial performance of listed banks in Nigeria Stock Exchange.

\section{The scope of the study}

This study combined theoretical considerations (Contingency theory, and Agency theory,). The theories were found relevant in view of the practice of contingency theory approach provides an explanation of the diversity of Market Risk Hedging in reality and Agency theory is one of the corporate governing mechanism use for "the separation of ownership and control" which leads to conflict of interest, and sharing of risks. The study focuses on risk management in the Nigerian banking sector and how it has affected the financial performance of listed banks at the Nigeria Stock Exchange. This study gave special and specific focus to concept of risk management with a view to examining how to improve or enhance its practice in the Nigerian banking industry. The study population comprised of 28 listed banks at NSE that are actually engaged in risk management process whose financial performance impacts (otherwise) on the economic development of the country. The study's period is 10 years from 2009 to 2018. The scope of this study include the bank-specific attributes of Market Risk Hedging whose operational and professional roles in banking business cannot be quantified. This is a special attribute that impact on the financial performance of banks, generally.

\section{Literature Review}

Contingency Theory

The essence of a contingency theory of risk management is beyond the simple selection/correlation studies. Contingency Theory is propounded to find "fit" between contingent factors and MRH' Risk management practices, and to establish propositions of fit that will result in desired outcomes (Chenhall, 2006). Fiedler (1958) propounded contingency theory in his work leader attitudes and group effectiveness. He postulated that the effective leadership depends not only on the style of leading but on the control over a situation. There needs to be good leader-member relations, task with clear goals and procedures, and the ability for the leader to meet out rewards and punishments. The contingency theory of organizational structure presently provides a major framework for the study of organizational design (Donaldson, 1991). It holds that the most effective organizational structural design is where the structure fits the contingencies. It helps to understand the interrelationships within and among organizational subsystems as well as between the organizational system as an entity and its environments.

Donaldson (2001) has an approach to contingency quite soon in organization theory, he builds up three core factors of the research model applied in market risk hedging: (1) there is connection between contingency characteristics and market risk hedging structure; (2) contingency characteristics determines market risk hedging structure;(3) there is a fit of the level of the market risk hedging structure to each level of contingency characteristics. The interpretations about contingency are similar documents and control framework. The market risk hedging framework requirement of market risk is different due to organization characteristics. These differences are company size, culture, governance philosophy, objectives, operational environment (Greene, 2012). This statement presented in the IC framework (COSO 1992 and Basel 1998) is analogous to contingency theory that claims that each organization has to choose the most suitable control system by taking into account contingency characteristics (Donaldson \& Preston, 1995; Chenhall, 2003). For the above reasons, contingency theory forms a new approach to examine market risk hedging. The basic fundamentals of contingency theory are chosen to be the foundation of IC framework COSO and Basel. Contingency theory approach provides an explanation of the diversity of market risk hedging strategy in reality. Contingency theory provides an approach to research market risk hedging and its effectiveness. Contingency theory is a new method to examine risk management (Kiyota, 2011)

The adoption of contingency theory is based on the following assumptions: (i) the success of an organization depends on how it understands its environment; (ii) Market Risk Hedging (MRH) can become more efficient when designed to respond to environmental variables; and (iii) for the reason that environmental attributes are constantly changing, their implications for MRH require continuous evaluation (chenhall, 2003). The essence of the contingency theory is that organizational effectiveness results from an adjustment between organizational characteristics such as structure and strategy. The strategy refers to the way the company positions itself in the market ( Porter, 1994 ). Considering that the strategic posture of an organization can influence its Market Risk Hedging Strategy; it is necessary to understand how it interacts with the MRH system. 


\section{Empirical Review}

This section contains review of previous literature related to the effect of various risk management strategies on financial performance. Empirical review was done to identify the research and knowledge gaps in this field of risk management strategies and financial performance of listed banks at NSE.

Kirogo, Ngahu and Wagoki (2014) conducted a research in Nakuru town in Kenya on the effect of risk-based audit on financial performance. Inferential and Descriptive statistics was used to analyse the data. Since the population was a small number of 52 management employees in 27 insurance companies censure survey was employed in the study. Data was collected through the use of questionnaire. The analysis of the result was presented through mean, standard deviation and percentages. It was concluded that there were positive relationship between financial performance of insurance companies and risk based auditing.

Risk assessment enables the insurance companies to detect risks on time and concentrate on high risk areas leading to increased transparency and accountability and enhanced financial performance of insurance companies. Thus the study has found a strong association between risks monitoring practices as a control system and financial performance of insurance companies. This study will be conducted in listed banks which is basically money market as against capital market of insurance.

Gordon et al. (2015) conducted a study on the use of internal audit by Australian companies. The purpose of this study was to explore the voluntary use of internal audit by Australian publicly listed companies and to identify factors that lead to listed companies to have an internal audit function. To test the predictions, the study combined data from a survey of listed companies with information from corporate annual reports. The study also provided descriptive information on the use of internal audit. The result indicated that only one-third of the sample companies use internal audit. While size appeared to be the dominant driver, there is also a strong association between internal audit and the level of commitment to risk management. However, the study found only weak support for an association between the use of information processing and strong corporate performance. This study was based on Australian economy which is more developed than Nigerian economy and also researching on the effect of MRH and financial performance of listed banks at NSE.

Al-Matari, Al-SwidiandFadzil (2014) study focused on the effect of the internal audit and MRH performance. This study attempted to propose a structure of the relationships between the internal risk monitoring characteristics; the professional qualifications of the chief audit executive of the Internal Audit (IA), size, experience, and qualification; and performance. The presence of an internal audit department is significant as it is considered as the main element in employing accounting systems and this, in turn, assists in evaluating the department's work. The risk monitoring characteristics is deemed as the core of business accounting as it is the section that keeps track of all businesses associated with the sector. The internal audit efficiency assists in developing the company's work but the financial performance reports present a weak association.

Ziaee (2014) conducted a study on the effect of internal audit quality on the performance of listed companies in Tehran Stock Exchange. This study sought to examine the relationship between audit quality and financial performance of financial companies in Iran. For this population the financial risk management is accepted in Tehran Stock Exchange and 2008 to 2012 have been selected. Questionnaires were distributed and they reached the conclusion that audit quality could not affect the financial performance of companies. This study will examine the effect of market risk hedging on financial performance of listed banks in Nigeria with a secondary source data of audited financial report.

\section{Methodology Introduction}

The study used panel data to carry out the research analysis for 10 years starting from 2009 till 2018 . The study examined the data in order to know which model will be adopted from fixed effect and random effect model. In the case of fixed effect model, it was assumed that the variables that have effect on financial performance vary over time but have fixed effect across the entire period under study. Assumption of the fixed effect model include homogeneity of the estimates across the entities and the error term between the entities $\mu_{i t}$ is equal to zero. A fixed effect model assumes correlation between error term $\mu_{i t}$ and the predictor variables. However, in the case of a random effect model, the variation across entities is assumed to be random. The error term between the entities $\mu_{i t}$ is equal to zero and is estimated (Guharati, 2003).

The fixed effect model and random effect model is given in equation 1 and 2 respectively below:

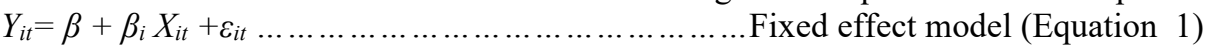

$Y_{i t}=\beta+\beta_{i} X_{i t}+\mu_{i t}+\varepsilon_{i t} \ldots \ldots \ldots \ldots \ldots \ldots \ldots \ldots \ldots \ldots \ldots$ Random effect model (Equation 2$)$

A Hausman test was carried out to investigate whether the data collected violated the assumption of the fixed effect model and to know which model to adopt. The null hypothesis for Hausman is the preferred model is the random effect model. The decision rule is based on Chi-Square statistic p-value of the Hausaman test less than 0.05 indicated that the preferred model is the random effect model otherwise, it is fixed effect (Torres-Reyna, 2007). The following model was used in line with the objectives of the study: 
$\mathrm{Y}_{\mathrm{it}}=\beta_{0}+\beta_{1} \mathrm{X}_{1 \text { it } \ldots \ldots \ldots \ldots \ldots \ldots .1}$

Where: $Y_{\text {it }}$-Dependent Variable:

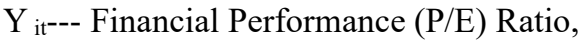

$\mathrm{X}_{1}=$ Market Risk Hedging.

\section{Findings}

The objective of the study was to establish the effect of market risk hedging on financial performance of listed banks at Nigeria Stock Exchange. The GLS was fitted to empirically determine the effect of Market Risk Hedging strategy on financial performance of listed banks at Nigeria Stock Exchange. The indicator was Market Risk Hedging strategy. The results of which were as presented in Table 1. The Wald Chi-square statistic was 6.74 with the p-value of 0.0094 for Market Risk Hedging strategy which is less than the alpha value $=0.05$. The implication of this was that the GLS model fitted is generally significant and that the estimated coefficients of the explanatory variables are jointly equal to zero. This means that Market Risk Hedging strategy has significant effect on the financial performance of the listed banks at Nigeria stock Exchange.

Table 1: Generalized Least Squares Model Summary for Market Risk Hedging Strategy

Coefficients: generalized least squares

Panels: homoscedatic

\begin{tabular}{lclr}
\hline Model Statistics & & \multicolumn{1}{c}{ Panel observation } \\
\hline & 1 & Number of obs & 200 \\
Estimated covariances & 0 & Number of groups & 199 \\
Estimated autocorrelations & 2 & Obs. Per group: min & 1 \\
Estimated coefficients & 6.74 & & \\
Wald chi2(4) & 0.0094 & & \\
Prob $>$ chi2 & & \\
\hline
\end{tabular}

The model coefficients estimates are presented in Table 2 The coefficient estimate of Market Risk Hedging strategy was found to be 0.001923 with z statistic 2.60 . The p-value of the coefficient was less than 0.05 . This implied that Market Risk Hedging strategy has effect on the financial performance of the listed banks at Nigeria stock Exchange. This result was similar to the findings of Faisal, Melati, Lim, and Hashim (2011). However, it contradicts the findings of Al-Matari, Al-Swidi and Fadzil (2014). The equation generated from the model fitted is given next.

$Y_{i t}=.0001636+.001963 C S_{\text {IACit }}$

Table 2: Coefficients Table- Generalized Least Squares Univariate Model for Market Risk Hedging Strategy

\begin{tabular}{lllll}
\hline & Coefficient & Std. Err. & $\mathbf{Z}$ & $\mathbf{P}>|\mathbf{z}|$ \\
\hline CS $_{\text {IAC }}$ & .001923 & .0007405 & 2.60 & 0.009 \\
Constant & .0001636 & .0004738 & 0.35 & 0.730 \\
\hline
\end{tabular}

Market Risk Hedging Strategy and financial performance of listed Banks at NSE

The objective is to investigate the market risk hedging strategy and financial performance of listed Banks at NSE. The result from the descriptive statistics indicated that bank risk monitoring activities has a high mean value with low degree of variability and dispersions in the model. This suggests that not many banks were all involved in the practice of market risk hedging activities. It might however be possible that they were using other risk management strategies during the period. The coefficients of correlation showed that market risk hedging activities was positively related to financial performance of the banks. Panel least regression analysis also confirmed and market risk hedging strategy has statistical significant influence on financial performance of the listed banks. The relevant theories which could interpret these findings are: contingency theory stating that each organization has to choose the most suitable monitoring systems by taking into account suitable contingency characteristics especially in a dynamic and turbulent environment like Nigeria.

\section{Recommendations}

With increased competition, the need to be efficient in banking operation requires continuous update of knowledge all over the world. Drawing from the findings and the conclusions of this study, the following recommendations (managerial and policy based) are presented so as to improve risk management and financial performance of listed banks at Nigeria Stock Exchange.

\section{Managerial Recommendation}

Market Risk Hedging strategy for the banks must be improved for it to commensurate with present operational activities or realities of the banks. Its review must be the focus of the regulators of the industry and should be continuous or time frame bound. Banks should also work on their operational expenses particularly overhead 
which constitute larger part of the expenses they daily incur. This will no doubt go a long way to reducing total expenses of the banks and improve profitability and financial performance generally for the listed banks. They should specifically work on share price and earnings of the banks as a major components of the bank's financial performance.

\section{Policy Recommendation}

The present risk monitoring process laid down by the CBN seems not to be adequate for the present banking activities in Nigeria anymore. In agreement with prior recommendations, the regulatory and monitoring machinery of the CBN and other allied institutions should improve on the use of ICT. The IMF report of Article IV consultation had advised the $\mathrm{CBN}$ to conduct risk management review, so as to identify any potential risk management requirements for the Nigerian banking system. To this end, credit risk management reporting as a vital instrument to monitoring bad loan/credit management is advocated for all banks, in line with the submission of the Credit Bureau Association of Nigeria.

\section{References}

Adebiyi, W.K. (2016). Corporate governance and financial reporting quality of deposit money banks in Nigeria. Doctoral thesis of Nasarawa State University, Nigeria.

Al-Matari, E. M., Al-Swidi, A. \& Fadzil, F. H. B. (2014). The effect of the internal audit and MRH performance: a proposed research framework. International Review of Management and Marketing, 4(1), 34. America Economic Review, 63(2), 134-139

Anastasiadou, D. (2011). Corporate governance and MRH profitability. African Journal of Business Management, 4(3), 126-.139

Casu, B., Girardone, C., \& Molyneux P. (2006). Introduction to banking. Essex, England: Pearson Education Limited.

CBN (2012) Exposure Draft CODE for Banks in Nigeria. Central Bank of Nigeria (CBN). [11].

CBN Deputy Governor. (2011) Financial system stability, Dr.Chiedu K. Moghalu, remark made at the 2011 global policy forum of the Alliance for Financial Inclusion (AFI), in Mexico.

Chenhall, R. H. (2003). Management control systems design within its organizational context: findings from contingency-based research and directions for the future. Accounting, Organizations and Society, 28(2-3), 127-168. http://dx.doi.org/10.1016/S0361-3682(01)00027-7.

Chenhall, R.H. (2006). The contingent design of performance measures. In Bhimani, A. (Ed.). Contemporary Issues in Management Accounting, 92-116. New York: Oxford University Press, USA.

Damodaran, A. (2013). Corporate Finance: Theory and Practice, (2nd ed.). New Delhi: John Wiley and Sons.

Doaei, M., Ahmad-Anuar, M. \& Ismail, Z. (2014).Diversification and financial performance in Bursa Malaysia. International Journal of Management and Business Research, 4(4), 309-317.

Donaldson, L. \& Davies, H. (1991). Stewardship Theory or Agency Theory: CEO Governance and Shareholder Returns. Australian Journal of Management.49-65.

Donaldson, T. \& Preston, L.E. (1995). The stakeholder theory of the corporation: concepts, evidence and implications. Academy of Management Review, 20(1), 65-91.

Eikenhout, L. C. A. (2015). Risk management and performance in insurance companies. Unpublishedd Master's thesis, University of Twente.

Faisal .K., Melati .A., Lim. G. C. \& Hashim. K.(2011), Determinants of Bank Profitability in Pakistan: A Case Study of Pakistani Banking Sector, World Applied Sciences Journal 15 (10): 1484-1493, 2011 ISSN 18184952

Fernando, W.D.I., \& Ekanayake, E.M.N. (2015). Do commercial banks use loan provisions to smooth their income? Empirical evidence from Sri Lankan CBs. Journal of Finance and Bank Management, 3(1), 167-179.

Gordon, L. A., Loeb, M. P. \& Tseng, C. Y. (2015). Enterprise risk management and MRH performance: A contingency perspective. Journal of Accounting and Public Policy, 28(4), 301-327.

Greene, W.H. (2012). Econometric analysis. ( $7^{\text {th }}$ Ed.). Essex, England: Pearson Education Limited, International Edition.

Harner, M. M. (2010). Barriers to effective risk management. Seton Hall L. Rev., 40, 1323.

Jeroh, E. \& Okoye, E. (2015). Impact of Assessment of Bank Consolidation on the Performance of Commercial Banks in Nigeria. Acta Universitatis Danubiusconomica, 11(5), 45-52.

Kirogo, A., Ngahu, E., Wagoki, K. (2014). Effect of Risk-Based Audit on Financial Performance: A Survey of Insurance Companies in Nakuru Town, Kenya IOSR Journal of Business and Management, 16(10), 84 - 91.

Kiyota, H. (2011). Efficiency of commercial banks in Sub-Saharan Africa: A comparative analysis of domestic and foreign banks (No 58). Helsniki.

Kolapo, T. F., Ayeni, R. K. \& Oke, M. O. (2012). Credit risk and commercial banks' performance in Nigeria: A panel model approach. Australian Journal of Business and Management Research, 2 (2), 31-38. [25]. L 
Mitnick, B. M. (1973). Fiduciary rationality and public policy: the theory of agency and some consequences. Paper presented at the 1973 Annual Meeting of the American Political Science Association; New Orleans, LA in Proceedings of the APSA.

Mohammad, A.A., Sheila, N.N., Hafiz, M.A. \& Ahamed, K.M. (2014). A panel data analysis on the relationship between corporate governance and bank efficiency. Journal of Accounting, Finance and Economics, 1(1), 115.

Njogo, B. O. (2012). Risk management in the Nigerian banking industry.Kuwait Chapter of Arabian Journal of Business and Management Review, 1(10), 100-109

Owojori, A. A., Akintoye, I. R. \& Adidu, F. A. (2011). The challenge of risk management in Nigerian banks in the post consolidation era. Journal of Accounting and Taxation, 3 (2), 23-31.

Porter, M. E. (1994). Estrategia competitiva:tecnicas para analise de industrias e da concorrencia (E. M. Braga, Trad., 8. ed.). Rio de Janeiro: Campus.

Salehi, M. (2008). The role of financial intermediaries in capital markets. Zagreb International Review of Economics and Business, 11(1), 97-109.

Santarelli, E. \& Tran, H. T. (2013). Diversification strategies and MRH performance: a sample selection approach. International Journal of Management and Business Research, 6(4), 109-115.

Soludo, C. (2004). Consolidating Nigerian banking industry to meet the development challenges of the $21^{\text {st }}$ century. Being a Paper Delivered to the Special Meeting of the Bankers' Committee Held on July 6, 2004 at CBN Headquarters Abuja, 3-8.

Tahir, I. \& Razali, A. (2012). The relation between Enterprise Risk Management and MRHvalue: Evidence from Malaysian Public listed Companies. International Journal of Economics and Management, 1(2), 32-41.

Umoren, A.O. \& Enang, E.R. (2015). IFRS adoption and value relevance of financial statements of Nigerian listed banks. International Journal of Financial and Accounting, 4(1), 1-7.

Williamson, O. (1979). Transaction-cost economics: The governance of contractual relations. Journal of Law and Economics, 2(2), 233-261.

Ziaee, M. (2014).The effect of audit quality on the performance of listed companies in Tehran Stock Exchange. International Letters of Social and Humanistic Sciences, (21), 36-43. 